\title{
Innovative Project Thinking of Designers as a Pedagogical Issue
}

\author{
Natalia Ivanovna Anufrieva ${ }^{1, *}$, Ekaterina Yuryevna Ivanova ${ }^{2}$, Marina Viktorovna Pereverzeva ${ }^{1}$, \\ Lena Igorevna Cheshenko ${ }^{2}$, Vera Aleksandrovna Ovsyannikova ${ }^{2}$ \\ ${ }^{1}$ Department of Sociology and Philosophy of Culture, Russian State Social University, Russia \\ ${ }^{2}$ Department of Arts and Artistic Creation, Russian State Social University, Russia
}

Received February 21, 2020; Revised April 8, 2020; Accepted April 19, 2020

Copyright $\mathrm{C} 2020$ by authors, all rights reserved. Authors agree that this article remains permanently open access under the terms of the Creative Commons Attribution License 4.0 International License

\begin{abstract}
The leading trend in the 21st century is an innovative approach in science, education, and culture, manifested in various spheres of human activity especially those related to the creative transformation and improvement of the world. Thus, the study of the development and functioning of heuristic thinking of designers, associated with innovative ideas and concepts of material culture, is becoming increasingly relevant. The emergence of such professions as creative state moderator or mental fitness coach has been predicted. The purpose of the study is to identify pedagogical technologies aimed at the formation of innovative thinking necessary for a designer's project activity. Designers should be trained based on innovative projects, brainstorming methods, problem-based tasks, and cases, ensuring that students master the system of values, meanings, and models of innovative creative activity. Only then will design projects launch the process of deliberate change that introduces qualitative changes into the environment. Innovative project thinking is a universal competence of designers, necessary for successful professional activities in the modern world in its various forms and types. Therefore, its formation is one of the most important pedagogical problems of today. A new aspect of the study is the methodological recommendations on the training of designers in innovative thinking, which includes three stages of this process: creating an object, assessing the degree of novelty, and mastering in real life. As practice has shown, students form innovative thinking in the classroom if they comprehend innovative projects from the concept to the specific implementation and assessment of the result.
\end{abstract}

Keywords Innovation, Project, Design, Thinking, Pedagogy, Training, Methods

\section{Introduction}

The implementation of various design projects is caused by the need for the simultaneous renewal, conservation, and increase of scientific and artistic achievements of culture, as well as the modelling of future environments, since design is "a specific sphere of activity associated with the development of object and spatial environments and aimed at providing results with high aesthetic qualities, optimization and harmonization of their interaction with a person, society, and natural environment" [1]. Creative development and innovation in any sphere of human activity require an innovative approach on the part of scientists or artists, as well as an innovative paradigm, determining the development of science and art and supported at the state level [2]. Humanity's intellectual and creative achievements have always been associated with a high level of social engagement. Innovation "is a feature of modern thinking and suggests manifestation of creativity in a creative act" [3].

\section{Methods}

\subsection{General Description}

Research project: to identify the specifics of the of stages of a design project, determining the methodology of training designers and its focus on innovative projects; to develop and introduce problem-based tasks or cases into pedagogical practice and analyze the mechanism for the development of innovative thinking in designer-students. An experimental study was conducted based on the Russian State Social University in 2019. The research approaches included analysis of the scientific literature on the specifics of innovative thinking and the stages of its application; generalization of pedagogical 
practice and the identification of the conformity of methodological approaches to the goal of formation of innovative thinking; pedagogical process, which implies the use of specially developed methods and tasks aimed at the formation of innovative thinking in designer-students.

No statistical tools were used in the study.

The study of innovative processes based on the culturological approach has been conducted by A.I. Arnoldov, S.N. Ikonnikova, M.S. Kagan, and others. The conceptual justification of the implementation of laws and principles of innovation has been conducted by M.M. Potashnik, L.S. Podymova, and A.V. Khutorskoy. The essence of innovation has been described by F. Bezrudny, V.S. Dudchenko, and O.S. Sovetova. The project activity of designers, both in general and in terms of innovation, has been considered in works by M.S. Myshinskaya, O.V. Kaukina, R.Y. Ovchinnikova, M.V. Pankina, O.P. Tarasova, O.R. Khaliullina, V.T. Shimko, and others. Literature regarding modern educational technology is extensive as well [4].

\subsection{Algorithm}

However, pedagogical technology aimed at the formation of innovative thinking, necessary for the project activity of a designer, is neglected [5]. In part, this is due to the scope of the concept of innovative project design and the complexity of the development of a methodology for the formation of heuristic thinking. "The heuristic method is the organization of search and creative activities based on the theory of stage-by-stage acquisition of knowledge and methods" [6]. Some believe that many people naturally "lack" it. However, pedagogical practice proves that in certain organizational and methodological conditions, innovative project thinking is formed in students at a level sufficient for successful professional activity.

Modern scientific knowledge in the aforementioned fields proves that the transfer of technocratic recipes of innovation to project design does not solve the pedagogical problem of the formation of innovative project thinking in student designers. However, this is possible in the study of the psychological mechanisms and factors of innovative thinking of designers, features of project activity, as well as the development of organizational conditions and methods based on the understanding of the nature of innovative project thinking of designers [7].

\section{Results}

The project design of new material and spiritual values, objects and technologies of aesthetic transformation of the environment determines the specifics of this field of creativity [8]. Schematically, innovative project design can be presented as a stage-by-stage transition from the analysis of a problem task and search for the solution to concept development and implementation of innovation in real life [9]. A mandatory component is the assessment of the result and its application in real life. This aspect is usually given little attention, which was the focus of this study.

The implementation of these stages of project design ensures project thinking, which, according to Ovchinnikova, has a complex structure, consisting of natural-scientific, technical, and humanitarian knowledge, as well as engineering and artistic thinking [10]. At the same time, "creativity is a measure of the originality of project thinking. The creative process is a constant search for differences from others" [10]. Thus, innovative and project thinking of designers are two sides of the same coin - a heuristic approach to creative activity. This type of thinking synthesizes processes of engineering and artistic work of intellect since "design develops and accumulates its artistic and project potential based on new artistic means, developed by artists in the process of solving their creative problems" [11].

As scholars believe, "the success of project design is determined by the designer's project thinking. The process of creation of an object suggests the synthesis of imagination and logic of the author, in which the future object serves as a proposal related to the solution to a problem using artistic means, aimed to have a certain emotional effect on the consumer" [10].

Design is considered as "social and cultural phenomenon with a certain system of values, norms of professional activity, and principles of project design. In connection with this, the culturological approach to design as a mass culture phenomenon seems most relevant" [12]. From the position of the culturological approach, when working on a project, one must pay special attention to the combination of organizational, technological, technical, motivational, value, and aesthetic aspects with artistic, creative, spiritual, and moral components [13].

A modern innovative approach in project design "is formed on an interdisciplinary basis as a result of the transfer and non-standard recombination of knowledge and skills from one field of knowledge or activity to another" [3]. The professional project activity of a designer develops based on the integration of professional operational and universal metaknowledge, providing the intellectual and creative work of a person.

Operational knowledge is acquired in the process of practical creative activity and development of creative abilities of a designer, as well as the acquisition of technical skills and experience of project activity [5]. "The use of various types of tasks requiring creative, non-standard solutions encourages students to achieve optimal results in any activity and develop professionally" [6].

Metaknowledge develops as a result of the analysis of ready design products of an innovative nature. Both types of study tasks are usually present in higher education 
programs. However, they often lack didactic principles, aimed at the development of innovative project thinking in particular and creative abilities in general since "a distinguishing feature of project activity is the opportunity to provide the formation of new ideas, emergence of new meanings, and dynamics of values in parallel with the creation of a project" [14].

An important role in the formation of an innovative approach to project design is played by the organization of creative space and atmosphere, as well as the "situation of success". A higher education institution must provide the conditions for the creative self-realization of students: creative abilities and innovative thinking are developed with problem tasks with multiple "unknowns", competitions requiring independent decision-making, group project activity, search for solutions to complex problems in cooperation with teachers [15]. The general goal of designer training is the formation of creative abilities in students based on fundamental knowledge and professional skills.

The components of creative activity include such categories as innovative solution, originality of conception, non-standard implementation, generation of ideas, and vision of perspective implementation of innovation [16]. These qualities are rarely natural and require various approaches and methods related to brainstorming, problem tasks, or cases. Only the search for non-standard solutions, as well as creative development pedagogical technology, encourages the formation of innovative project thinking of student designers $[17,18]$.

Designer training based on theoretical and practical material ensures the development of creative potential. A designer as a representative of creative activity must possess a heuristic mindset, capable of supporting and implementing innovative design projects. The object of creative innovation is a system of values, meanings, and models of a person's creative self-realization while its result is implemented purposeful projects as factors of qualitative changes in this system [19].

Thus, designer training must be based on innovative projects and methods of brainstorming, problem tasks, or cases, which ensures an acquisition by students of the system of values, meanings, and models of innovative creative activity. Only then, design projects start the process of qualitative change in the environment.

In the framework of the formation of innovative thinking of designers at classes devoted to project design, students participated in the case study "Urbanistic conceptions of the future". The case study was based on documents and visual materials about US megalopolises as city toposes, which played an important symbolic role even at the earliest stages of American history and, thus, received original urbanistic conceptions at the stage of their project design. As materials for the case study, we used not only state documents, photo, and video of modern megalopolises, the conceptions which the student designers were to consider, but also numerous literary works, in which city space becomes an artistic construct of creative mind: fragments from novels by Paul Auster, James Jones, Jonathan Safran Foer, and others, as well as impressions of contemporaries - images of New York as perceived by Russian and foreign visitors.

In the process of urbanization, US cities came to be associated with dynamic symbolic meanings. These symbols are determined by the project design of the cities, the development and implementation which follows a formed conception - an image, determining the technical and artistic means of its implementation. Successful design is hardly possible without the creative component - the ability to see and create artistic images. One cannot ignore methods of creative development based on the means of different art forms. An example of creative thinking stimulation is the method of analysis of an artistic image in a literary work.

In the process of problem-solving, student designers studied fragments from the novel "The Music of Chance" (1990) by Auster where the city symbolizes a totalitarian model, a place of order and control. A fragment of the novel is set in the estate of millionaires, one of which is busy building a model of the City of the World. The model is built with accuracy and precision and occupies a whole room. The writer, having mastered creative thinking, uses his images as clues to designers of innovative projects of the city of the future. The characters of the novel consider the model city as an ideal embodiment, ruled by wisdom and order. This image of the city of the future and its urbanistic concept stimulate the designer's imagination, developing their creative mind.

A brainstorming task was related to the determination of the conception in architecture and painting, created by several innovators at the beginning of the 20th century. The students were presented with photographs of famous (but unknown to the students at the time) buildings by Le Corbusier and Ludwig Mies van der Rohe, as well as reproductions of works by Willem de Kooning, Mark Rothko, and Jackson Pollock.

These projects were implemented in the 1910-40s and remain masterpieces of avant-garde architecture, whose ideas and images stimulate young designers' imaginations and encourage them to work on their own innovative developments. However, for these developments to be implemented, a heuristic approach to problem task solving is required, which is mastered in the process of solving similar tasks. The students independently identified and formulated innovative conceptions of the architects and searched for evidence of their implementation in terms of specific artistic means, techniques, features, and qualities of implemented projects.

Stylistic features of Le Corbusier's works include "objects elevated above the ground and supported by columns, flat roof terraces, used as gardens, transparent 
facades, open interiors with the 'free plan', allowing one to avoid isolated rooms and go from one room to another" $[15$, p. 40]. Mies van der Rohe created several glass houses free of interior supports in the most picturesque parts of America. His ideas were inspired by the philosophy of naturalism: glass walls of the buildings seemingly dissolve in the forest landscape and reunite humanity with flora and fauna. One of his glass houses, sitting on a floodplain, "hovers in space, accentuating the ephemerality of the building free of interior supports" [20].

\section{Discussion}

In the process of analysis of works by the representatives of abstract expressionism, the students considered the psychological, mythological, and biomorphic basis of their works. According to the students' conclusions, Kooning, Rothko, and Pollock search for the unconsciousness as the core of universality. In the painting entitled "Excavation", the students studied how Kooning's line creates intertwined organic shapes. His line roams, disappearing and suddenly reappearing in different parts of the painting. The students noted the profound ambiguity of the meaning, which was the goal for the students to find the hidden meaning and develop innovative thinking, seeing the essence of every seemingly random detail.

The outlines of the abstract images in the painting by Kooning remind the students of either landscapes of hills and valleys, or a blurry figure, or fantasy scenery - each student designer interpreted the work in their own way, considering different options and developing heuristic thinking, inspired by Kooning's everliving and restless line that never creates any closed or visible contours. It forms an equally restless mind. Kooning cultivates the elusiveness of an image, teaching a researcher attitude towards reality.

Pollock's automatism relying on physical gesture, fluid space, and elusive images, as well as the absence of complete and closed shapes, gives the students participating in the tasks an opportunity to go beyond limitations canons, precise structures and definitions, allowing one to achieve intellectual breakthrough through the familiar, obvious, and understandable. There are still many things in the world that go beyond comprehension and require an innovative approach to the explanation of phenomena and processes of the world.

These original project solutions of geniuses of architecture and painting, which in the process of student training turn into metaknowledge, related to the mechanisms and instruments of innovative project design and intellectual and creative activity, encourage the formation of heuristic thinking in designers. The mechanism of generation of innovative ideas in people of creative professions is similar to the technology in the search for answers to the original mysteries of innovative works of art, the study of which serves as an effective method of formation of innovative project thinking of designers.

\section{Conclusions}

The essence of innovative project design is related to the creative development and implementation of innovation in the environment. Hence there are three stages of this process: the creation of an object, assessment of the degree of innovation, and implementation in real life. Thus, the students studied innovative projects comprehensively: from the concept to its implementation and assessment. However, the successful formation of innovative project thinking of designers requires more evidence-based data on structural and processual features of innovative thinking and psychological and pedagogical determinants of its development.

In project design, it is important to determine the means of individual creativity and artistic performance, which together create a new cultural product since an innovative approach in design captures key issues in the development of culture and society. The forecast of creative activity result and the development of project implementation strategy lead the designer in an innovative direction and guarantee the development of successful products, satisfying the demand of modern society.

Artistic and creative work, as well as innovative project design, serves as a means of organizing the activity of a team, for example, a design bureau or studio, allowing the goal of the project without wasting resources. Criteria for the choice of strategy are competitiveness, effectiveness, orientation on human capital, and artistic freedom. In the project approach, activity of a team or institution is divided into relatively independent blocks, each of which has its own goal and direction while sharing resources. A project allows a creative team to be more flexible and competitive in the changing socio-cultural conditions.

\section{REFERENCES}

[1] O. V. Kaukina. Metodologicheskiy aspect formirovaniya proektnoy kultury budushchikh dizaynerov $\mathrm{v}$ protsesse professionalnoy podgotovki [Methodological aspect of the formation of project culture of future designers in the process of professional training], Vestnik Volzhskogo iniversiteta im. V.N. Tatishcheva, Vol. 4, No. 19, 102-109, 2015.

[2] F. Bezrudny, O. Nechaeva, G. Smirnova. Sushchnost ponyatiya innovatsii i ego klassifikatsiya [The essence of the concept of innovation and its classification], Innovatsii, 
Vol. 2-3, 1998.

[3] O. P. Tarasova, O. R. Khaliullina. Sushchnostnaya kharakteristika strukturnykh komponentov ponyatiy "proetnost" $i$ "kreativnost" $v$ kontekste dizayn-deyatelnosti [Essential characteristics of the structural components of the concepts "project" and "creativity" in the context of design activity], Vestnik Orenburgskogo gosudarstvennogo universiteta, Vol. 5, No. 180, 231-236, 2015.

[4] G. K. Selevko. Sovremennye obrazovatelnay tekhnologii [Modern educational technology], Narodnoe obrazovanie, Moscow, 1998.

[5] V. T. Shimko. Osnovy dizayna i sredovoe proektirovanie [Basics of design and environmental project design], Arkhitektura-S, Moscow, 2005.

[6] M. S. Krivoshchekova. Proektny dizayn i dizayn proektirovaniya $\mathrm{v}$ razvitii professionalnoy napravlennosti budushchego pedagoga [Project design in the professional development of the future pedagogue], Spetsialnoe obrazovanie, Vol. 4, 121-130, 2011.

[7] O. S. Sovetova. Osnovy sotsialnoy psikhologii innovatsiy [Basis of the social psychology of innovation], SPbGU, Saint Petersburg, 2010.

[8] E. N. Lazarev. Dizayn kak tekhniko-esteticheskaya sistema [Design as a technical and aesthetic system], Moscow, 1984.

[9] L. A. Sinitsyna, E. Y. Rukavishnikova. Formirovanie idei i etapy dizayn-proektirovaniya na primere maketa knigi [Formation of an idea a design project stages based on the example of a book proof], Kontsept, Vol. 6(s), 2014, Online available from http://e-koncept.ru/2014/14571.htm.

[10] R. Y. Ovchinnikova. Dizayn-proektirovanie: teoreticheskie osnovaniya i spetsifika [Project design: Theoretical basis and specifics], Omskiy nauchny vestnik, Vol. 1, No. 105, 267-270, 2012.

[11] M. A. Morozova. Vliyanie khudozhestvennogo pop-arta na dizayn-proektirovanie vtoroy poloviny XX veka [The influence of pop art on design in the second half of the 20th century], Izvestiya Rossiyskogo gosudarstvennogo pedagogicheskogo universiteta im. A.I. Gertsena, 177-184, 2008.

[12] M. V. Pankina. Evolutsiya printsipov dizayn-proektirovaniya: kultirologicheskiy analiz [The evolution of the principles of project design: Cultorological analysis], Vestnik Chelyabinskoy gosudarstvennoy akademii kultury i iskusstva, Vol. 2, No. 38, 50-55, 2014.

[13] A. I. Arnoldov. Kulturnaya politika: realii i tendentsii [Cultural policy: Realities and tendencies], MGUKI, Moscow, 2002.

[14] S. A. Kurnosova. Etapy proektirovaniya pedagogicheskogo dizayna [Stages of pegagogical project design], Vestnik ChGPU, Vol. 9, 72-78, 2011.

[15] V. S. Dudchenko. Innovatsionnaya igra kak metod issledovaniya i razvitiya organizatsiy [Innovative game as a method of research and development at enterprises], Novovvedeniya v organizatsiyakh. VNIISI, Moscow, 54-69, 1983.

[16] M. S. Kagan. Filosofiya kultury [Philosohy of culture].
Petropolis, Saint Petersburg, 1996.

[17] Innovatsionnye formy i metody $\mathrm{v}$ sisteme khudozhestvennogo obrazovaniya (izobrazitelnoe iskusstvo): sb. dokl. regional. ped. konf. [Innovative forms and methods in the system of art education (visual arts): Collection of articles of the regional pedagogical conference], Tomsk. obl. ucheb.-metod. tsentr kultury i iskusstva, Tomsk, 2010.

[18] M. S. Myshinskaya, O. V. Kaukina. Individualizatsiya tvorcheskogo razvitiya studentov $\mathrm{V}$ protsesse dizayn-obrazovaniya [Individualization of creative development of students in the process of designer training], Sibirskiy pedagogicheskiy zhurnal, Vol. 12, 359-364, 2009.

[19] S. N. Ikonnikova. Kulturnoe prostranstvo kak tsennost i natsionalnoe dostoyanie [Cultural space as a value and national treasure], Istoriya kulturologicheskikh teoriy [The history of culturological theories], Piter, Saint Petersburg, 35-55, 2005.

[20] M. V. Pereverzeva. Aleatorika kak printsip kompositsii [Aleatoricism as a principle of composition], Lan, Planeta muzyki, Saint Petersburg, 2018. 